\title{
Accelerated Resensitization of the D1 Dopamine Receptor-mediated Response in Cultured Cortical and Striatal Neurons from the Rat: Respective Role of $\alpha 1$-Adrenergic and $\mathrm{N}$-methyl-D-aspartate Receptors
}

\author{
Fabrice Trovero, Philippe Marin, Jean-Pol Tassin, Joël Premont, and Jacques Glowinski \\ INSERM U 114, Chaire de Neuropharmacologie, Collège de France, 75231 Paris Cedex, France
}

\begin{abstract}
As previously shown in vivo, noradrenergic and glutamatergic neurons can regulate the denervation supersensitivity of D1 dopaminergic (DA) receptors in the rat prefrontal cortex and striatum respectively. Therefore, the effects of methoxamine (an $\alpha 1$-adrenergic agonist) and glutamate on the resensitization of D1 DA receptors were investigated in cultured cortical and striatal neurons from the embryonic rat. In the presence of sulpiride and propranolol, DA stimulated the D1 DA receptor-mediated conversion of ${ }^{3} \mathrm{H}$-adenine into ${ }^{3} \mathrm{H}$-CAMP in both intact cortical and striatal cells and these responses were markedly desensitized in cells preexposed for $15 \mathrm{~min}$ to DA $(50 \mu \mathrm{m})$. The complete recovery of the D1 DA response was more rapid in striatal $(15 \mathrm{~min})$ than in cortical $(80 \mathrm{~min})$ neurons. Methoxamine accelerated the resensitization of the $D 1$ response in cortical but not in striatal neurons. The effect of the $\alpha 1$-adrenergic agonist in cortical neurons was blocked by prazosin and chlorethylclonidine. In contrast, glutamate accelerated the resensitization of the D1 response in striatal but not in cortical neurons and the effect observed in striatal neurons was totally blocked by 2-amino-5-phosphonovaleric acid, an NMDA receptor antagonist. Protein kinase $C$ was shown to be involved in the $\alpha 1$. adrenergic-induced resensitization of the cortical D1 response but not in the glutamate-evoked resensitization of the striatal D1 response. Finally, for comparison, similar experiments were performed on $\beta$-adrenergic receptors using isoproterenol $(1 \mu \mathrm{M})$ as an agonist. Methoxamine did not modify the resensitization of the $\beta$-adrenergic response in cortical neurons, but glutamate accelerated the resensitization of this response in striatal neurons.
\end{abstract}

[Key words: cortical neurons, striatal neurons, D1 DA receptors, heterologous resensitization, a 1 -adrenergic receptors, NMDA receptors]

Several years ago, we provided behavioral and biochemical evidence for an interaction between the mesocorticoprefrontal dopaminergic (DA) neurons and the noradrenergic neurons originating from the locus coeruleus and innervating the cerebral

Received Jan. 13, 1994; revised Apr. 14, 1994; accepted Apr. 21, 1994.

This work was supported by grants from Institut National de la Santé et de la Recherche Mćdicale (INSERM) and Rhône Poulcnc Rorer. Wc thank Robert Williams for critical reading of the manuscript.

Correspondence should be addressed to Fabrice Trovero, INSERM U 114, Chaire de Neuropharmacologie, College de France, 11 Place Marcelin Berthelot, 75231 Paris Cedex, France.

Copyright $\odot 1994$ Society for Neuroscience $0270-6474 / 94 / 146280-09 \$ 05.00 / 0$ cortex. In the rat, bilateral electrolytic lesions of the mesencephalic ventral tegmental area induce a complex and permanent behavioral syndrome characterized by a locomotor hyperactivity and the incapacity of the animal to focalize its attention (Le Moal et al., 1969). Some of the behavioral deficits observed in the lesioned animals, particularly the locomotor hyperactivity, have been attributed for a large part to the selective destruction of the cortical dopaminergic (DA) innervation (Tassin et al., 1978). This locomotor hyperactivity was markedly reduced in rats with 6-hydroxydopamine (6-OHDA) lesions, which destroy not only the ascending DA neurons but also the ascending noradrenergic fibers passing near the ventral tegmental area (Tassin et al., 1982). $\alpha 1$-Adrenergic receptors sensitive to the $\alpha 1$ antagonist prazosin seem to play a prominent role in the permissive effect of cortical noradrenaline on the appearance of behavioral deficits in rats with ventral tegmental area electrolytic lesions. Indeed, in these lesioned animals, the peripheral injection of prazosin immediately suppressed locomotor hyperactivity (Trovero et al., 1992a). The effect of prazosin appears to be mediated at the cortical level since high affinity binding sites for prazosin were found in the prefrontal cortex, and the cortical application of prazosin abolished the increased locomotor activity evoked by amphetamine application into the nucleus accumbens (Blanc et al., 1993). In addition, the denervation supersensitivity of cortical DA-sensitive adenylate cyclase observed in rats with electrolytic lesions of the ventral tegmental area was prevented by the concomitant destruction of the cortical noradrenergic innervation (Tassin et al., 1982, 1986). Similarly, the denervation supersensitivity of the cortical DA-sensitive adenylate cyclase was not seen in rats with bilateral 6-hydroxydopamine (6-OHDA) lesions of the ventral tegmental area (Tassin et al., 1982).

Together, these behavioral and biochemical observations led us in the present study to determine whether the stimulation of $\alpha 1$-adrenergic receptors could regulate the sensitivity of the D1 DA-induced formation of cAMP (D1 response) in intact cortical neurons from rat embryos in primary culture. For this purpose, we first investigated the effect of an $\alpha 1$ agonist, methoxamine, on the recovery of the D1 response following a short-term DAinduced desensitization. For comparison, similar experiments were performed on cultured striatal neurons. Following this, the effects of glutamate on the rate of resensitization of the cortical and striatal D1 responses were also analyzed since the cerebral cortex is rich in glutamatergic neurons and the corticostriatal glutamatergic innervation has been shown to contribute to the regulation of the denervation supersensitivity of striatal D1 DA 

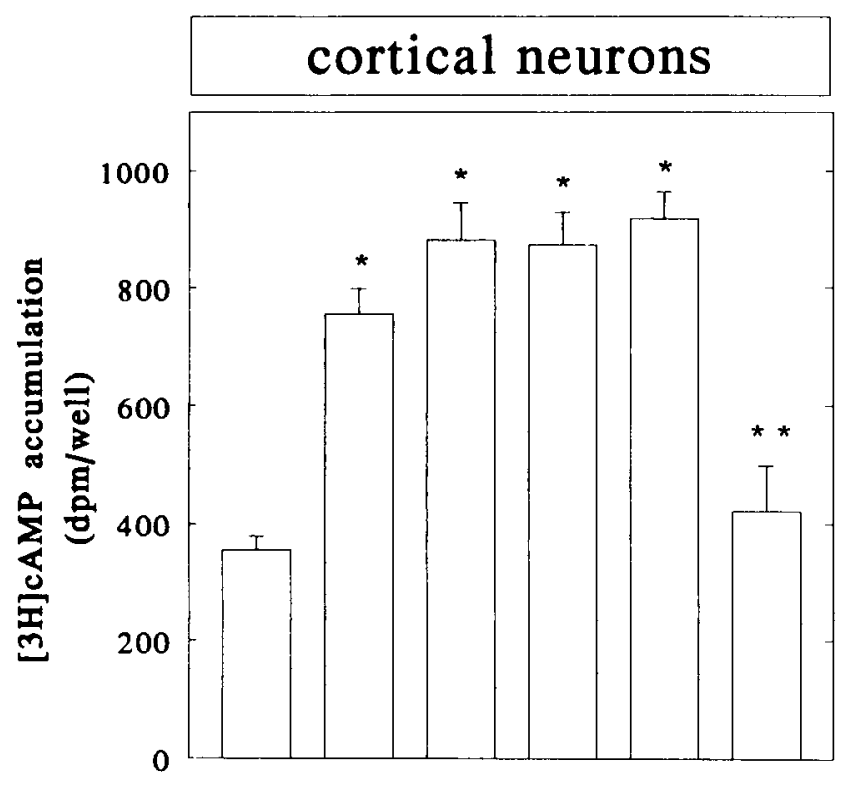

$\begin{array}{lcccccc}\text { Dopamine } & - & + & + & + & + & + \\ \text { Sulpiride } & - & - & + & + & + & + \\ \text { Propranolol } & - & - & - & + & + & + \\ \text { Yohimbine } & - & - & - & - & + & - \\ \text { SCH } 23390 & - & - & - & - & - & +\end{array}$

Figure 1. Pharmacological characterization of the dopamine-induced production of cAMP in cortical neurons. Cortical neurons from rat embryos were cultured for $6 \mathrm{~d}$ in serum-free medium and then incubated for $2 \mathrm{hr}$ with ${ }^{3} \mathrm{H}$-adenine. DA (50 $\left.\mu \mathrm{M}\right)$ and antagonists (sulpiride, $5 \mu \mathrm{M}$; propranolol, $1 \mu \mathrm{M}$; yohimbine, $1 \mu \mathrm{M}$; SCH 23390, 0.2 $\mu \mathrm{M}$ ) were then added to the medium in the presence of IBMX (1 mM) and incubated for $5 \mathrm{~min}$. The ${ }^{3} \mathrm{H}$-cAMP that accumulated in cells was then estimated. Neither sulpiride nor propranolol nor yohimbine significantly modified the response obtained with DA alone. Results are the mean \pm SEM of values obtained from triplicate in a typical experiment. *, significantly different ( $p<0.05$, Student's $t$ test) from basal values; ${ }^{* *}$, significantly different ( $p<0.05$, Student's $t$ test) from the DA-evoked response. Four other experiments performed with different cultures provided similar results.

receptors (Hervé ct al., 1989). Finally, in order to demonstratc further the specificity of the effects observed with methoxamine and glutamate, parallel experiments were made on the resensitization of the $\beta$-adrenergic-induced formation of $\operatorname{cAMP}(\beta$ adrenergic response), following isoproterenol-induced desensitization of $\beta$-adrenergic receptors in cortical and striatal neurons.

\section{Materials and Methods}

\section{Primary cultures of cortical and striatal neurons}

Cortices and striata were removed from $17 \mathrm{~d}$ old Sprague-Dawley rat embryos (Iffa Credo, Lyon, France) and mechanically dissociated in serum-free medium with a fire-narrowed Pasteur pipette. Cells were plated $\left(5.10^{5}\right.$ cells $\left./ \mathrm{ml}\right)$ on 24-well $(0.5 \mathrm{ml} /$ well $)$ Nunc culture dishes previously coated successively with poly-L-ornithine $(1.5 \mu \mathrm{g} / \mathrm{ml} ; \mathrm{MW}$, 40,000 ; Sigma) and culture medium containing $10 \%$ fetal calf serum. After removing the last coating solution, cells were seeded in a culture medium composed of a 1:1 mixture of Dulbecco's modified Eagle's medium (DMEM) and Ham's F12 nutrient (GIBCO, Paris), supplemented with glucose ( $33 \mathrm{~mm}$ ), glutamine ( $2 \mathrm{~mm}$ ), sodium bicarbonate ( $3 \mathrm{~mm}$ ), and HEPES buffer ( $5 \mathrm{~mm}, \mathrm{pH} 7.4)$. To this culture medium was added a mixture of hormones and salt composed of insulin $(25 \mu \mathrm{g} /$ $\mathrm{ml})$, transferrin $(100 \mu \mathrm{g} / \mathrm{ml})$, putrescine $(60 \mu \mathrm{g} / \mathrm{ml})$, progesterone $(20$ $\mathrm{nM}$ ), and sodium sclenatc ( $30 \mathrm{nM}$ ) (all from Sigma). After $6 \mathrm{~d}$ in culturc, more than $95 \%$ of the cells were immunocytochemically defined as neurons according to El Etr et al. (1989).

\section{${ }^{3} H-c A M P$ assay}

Cells cultured in 24 well culture dishes were incubated for $2 \mathrm{hr}$ with $2-{ }^{3} \mathrm{H}$-adenine $(27 \mathrm{Ci} / \mathrm{mmol}$, Amersham, $2 \mu \mathrm{Ci}$ per well containing 0.5 $\mathrm{ml}$ of culture medium).

Desensitization procedure. DA $(50 \mu \mathrm{M})$ was added to the culture medium $15 \mathrm{~min}$ before the end of ${ }^{3} \mathrm{H}$-adenine incorporation, in the presence of both propranolol $(1 \mu \mathrm{M})$ and sulpiride $(50 \mu \mathrm{M})$ to prevent $\beta$-adrenergic and D2 DA receptor stimulation.

Resensitization procedure. After removal of the desensitization medium, neurons were washed once with $0.5 \mathrm{ml}$ of Krebs' phosphate buffer (in mM: $\mathrm{NaCl}, 120 ; \mathrm{NaH}_{2} \mathrm{PO}_{4}, 15.6 ; \mathrm{KCl}, 4.8 ; \mathrm{MgSO}_{4}, 1.2 ; \mathrm{CaCl}_{2}, 1.2$ glucose, 33.3; $\mathrm{pH} 7.4$ ), and then incubated for the indicated time in 0.5 $\mathrm{ml}$ of the same medium containing appropriate agonists and/or antagonists.

${ }^{3} H$-cAMP measurement. After removal of the resensitization medium, cells were incubated for $5 \mathrm{~min}$ in $0.5 \mathrm{ml}$ of Krebs' phosphate buffer containing DA $(50 \mu \mathrm{M})$, sulpiride $(5 \mu \mathrm{M})$, propranolol $(1 \mu \mathrm{M})$, and the nonselective inhibitor of phosphodiesterases, 3-isobutyl-1-methylxanthine (IBMX; $1 \mathrm{mM}$ ). The incubation was stopped by replacing the medium with $0.5 \mathrm{ml}$ of ice-cold trichloroacetic acid (6\%). Cells were then scraped and $100 \mu \mathrm{l}$ of medium containing $1 \%$ SDS, $50 \mathrm{~mm}$ Tris$\mathrm{HCl}, 3 \mathrm{~mm}$ ATP, $3 \mathrm{~mm}$ cAMP, pH 7.4, was added to the samples. After centrifugation $(10 \mathrm{~min}$ at $12000 \times \mathrm{g})$, the labeled ATP and cAMP present in $0.5 \mathrm{ml}$ of supernatant were separated according to the procedure described by Salomon et al. (1974). Radioactivity was estimated in $10 \mathrm{ml}$ of Aquasol-2 (New England Nuclear-Du Pont) with a beta scintillation counter. Results, calculated as percentage of conversion of ${ }^{3} \mathrm{H}$-ATP into ${ }^{3} \mathrm{H}$-cAMP by $\left({ }^{3} \mathrm{H}\right.$-cAMP $\left.\times 100\right) /\left({ }^{3} \mathrm{H}\right.$-ATP $+{ }^{3} \mathrm{H}$-cAMP $)$, were expressed as a percentage of the basal values obtained without agonists.

\section{Inositol phospholipid turnover assay}

Neurons were incubated for $24 \mathrm{hr}$ in culture medium supplemented with $1 \mu \mathrm{Ci}$ /well of $m y o-{ }^{3} \mathrm{H}$-inositol. Cells were then preincubated for 10 min in Krebs' phosphate buffer supplemented with $\mathrm{LiCl}(10 \mathrm{~mm})$. Methoxamine $(100 \mu \mathrm{M})$ or glutamate $(100 \mu \mathrm{M})$ was then added for 20 min. The incubation was stopped by adding successively $200 \mu \mathrm{l}$ of $0.1 \%$ Triton X-100/0.1 м NaOH, $200 \mu \mathrm{l}$ of $0.1 \%$ Triton X-100/0.1 M HCl, and $500 \mu \mathrm{l}$ of water. Cells were then scraped, and ${ }^{3} \mathrm{H}$-inositol phosphates were extracted and estimated according to the procedure of El Etr et al., (1989).

\section{Results}

Desensitization of the D1 DA-induced formation of CAMP in cortical neurons by preexposure to $D A$

As illustrated in Figure 1, a 5 min exposure to DA stimulated the formation of ${ }^{3} \mathrm{H}$-cAMP in cortical neurons prelabeled with ${ }^{3} \mathrm{H}$-adenine $\left(\mathrm{EC}_{50}=1.5 \pm 0.2 \mu \mathrm{M}\right.$, mean $\pm \mathrm{SEM}$ calculated from three independent experiments, $n=3$ ). Most of the response to DA $(50 \mu \mathrm{M})$ was blocked by the D1 antagonist SCH $23390(0.2$ $\mu \mathrm{M})$, suggesting the involvement of D1 receptors in this process. The simultaneous addition of sulpiride $(5 \mu \mathrm{M})$ only slightly enhanced the DA-evoked response. Moreover, the addition of propranolol $(1 \mu \mathrm{M})$ or yohimbine $(1 \mu \mathrm{M})$ did not alter the DAinduced formation of ${ }^{3} \mathrm{H}$-cAMP, excluding the involvement of $\beta$ - and/or $\alpha 2$-adrenergic receptors (Fig. 1).

A reduction in the DA-induced formation of ${ }^{3} \mathrm{H}$-cAMP was observed when cortical neurons were preincubated for $15 \mathrm{~min}$ with DA $(50 \mu \mathrm{M})$ in the presence of both sulpiride $(5 \mu \mathrm{M})$ and propranolol $(1 \mu \mathrm{M})$. In fact, a comparison of the DA doseresponse curves in untreated and DA-preincubated cells revealed a marked decrease in the maximal response $(-55 \%, n$ $=10$ ) with only a weak but not significant reduction in the potency of DA (Fig. 2).

The DA-induced desensitization of the cortical D1 response was reversible. Indeed, a slow recovery of the initial D1 DA- 


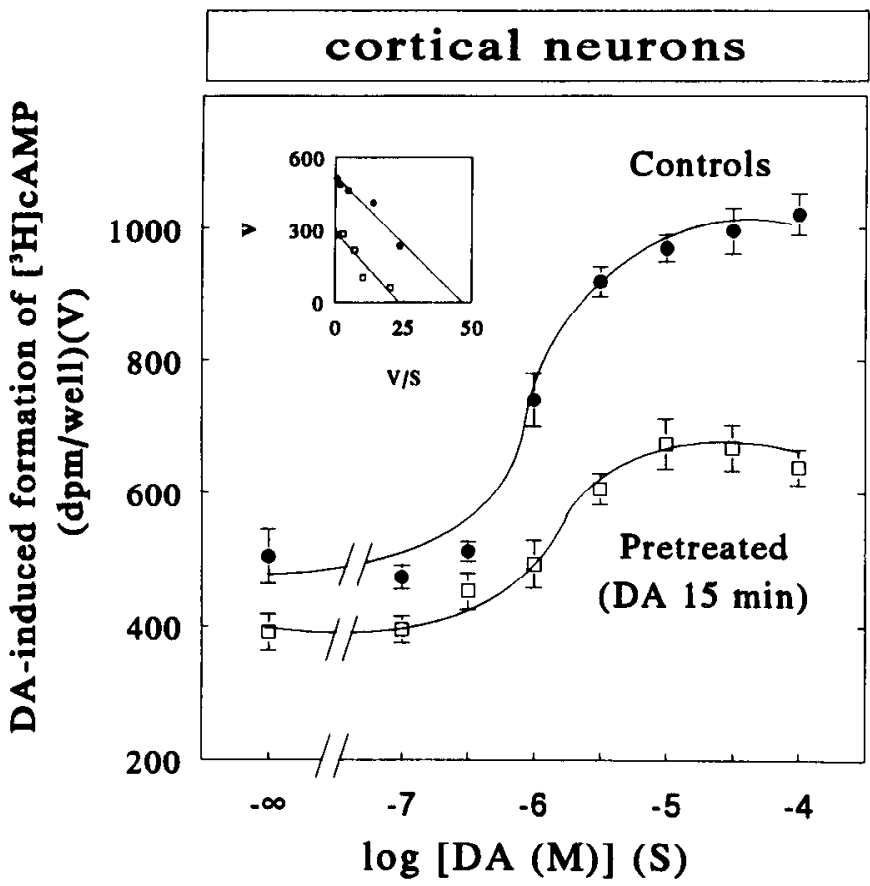

Figure 2. Dose-response curves for the D1 receptor-mediated formation of ${ }^{3} \mathrm{H}$-cAMP in cortical neurons pretreated with or without dopamine. Data represent the amount of ${ }^{3} \mathrm{H}$-cAMP produced $(V)$ when neurons were incubated for $5 \mathrm{~min}$ with increasing concentrations $(S)$ of DA in the presence of sulpiride $(5 \mu \mathrm{M})$ and propranolol $(1 \mu \mathrm{M})$, as described in Figure 1. DA-pretreated neurons were preincubated for 15 min in medium containing DA $(50 \mu \mathrm{M})$, sulpiride $(5 \mu \mathrm{M})$, and propranolol $(1 \mu \mathrm{M})$. Cells were then extensively washed with Krebs' phosphate buffer before the estimation of the dopamine-induced formation of ${ }^{3} \mathrm{H}$ cAMP as described above. Results are the mean \pm SEM of values obtained in an experiment performed in triplicate. Curves shown are representative of data obtained in three independent experiments made with different neuronal cultures. Inset, Eadie's representation of the data.

induced formation of ${ }^{3} \mathrm{H}$-cAMP could be observed in cortical neurons after the removal of DA, the half-maximal response being restored within $40 \mathrm{~min}$ and the total recovery of the full response being achieved after $80 \mathrm{~min}$ (Fig. 3).

Accelerated resensitization of the DI DA-induced formation of cAMP by stimulation of $\alpha 1$-adrenergic receptors in cortical neurons

The addition of methoxamine $(100 \mu \mathrm{M})$, an $\alpha 1$-adrenergic agonist, during the resensitization period of the cortical D1 response, accelerated the recovery of the D1 DA-induced formation of ${ }^{3} \mathrm{H}$-cAMP (Figs. 3, 4), without modifying the fully restored D1 response (estimated after a $80 \mathrm{~min}$ resensitization period) (Fig. 3). $\alpha 2$-Adrenergic receptors did not contribute to the effect of methoxamine since the $\alpha 1$ agonist-induced response was not affected by yohimbine ( $1 \mu \mathrm{M})$ (Fig. 4).

The accelerating effect of methoxamine on the resensitization of the D1 response was suppressed by prazosin $(1 \mu \mathrm{M})$, an $\alpha 1$ adrenergic antagonist (Fig. 4). The incubation of cortical neurons with chlorethylclonidine (CEC, $100 \mu \mathrm{M}$, added during 30 min before methoxamine addition), a compound that has been shown to inactivate $\alpha 1 \beta$-adrenergic receptors irreversibly (Han et al., 1987), also suppressed the effect of methoxamine (Fig. 4). In the absence of methoxamine, neither prazosin nor CEC affected the resensitization of the D1 response (Fig. 4). Interestingly, in contrast to methoxamine, glutamate $(100 \mu \mathrm{M})$, which
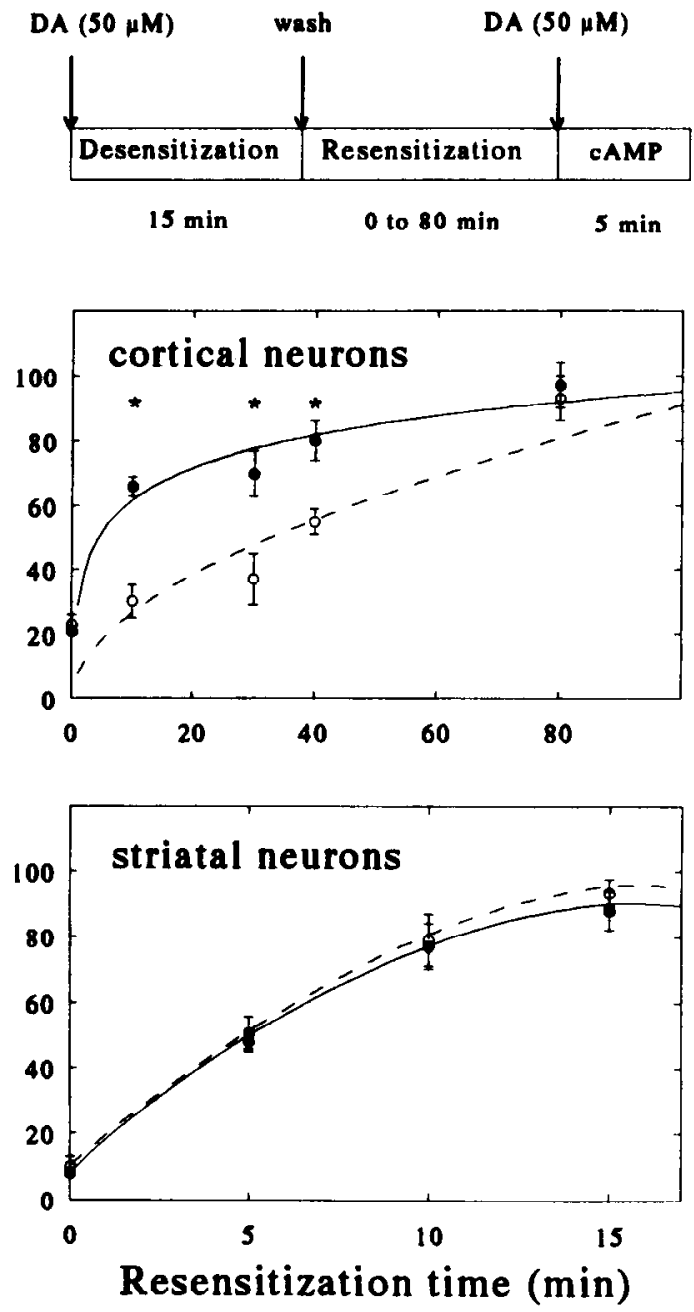

- - O- - control

methoxamine

Figure 3. Effects of methoxamine on the resensitization of the D1 response in cortical and striatal neurons. Neurons were preincubated for $15 \mathrm{~min}$ with DA $(50 \mu \mathrm{M})$ as described for Figure 2. Following washing (see Materials and Methods), cells were incubated for various times in the resensitization medium with or without methoxamine $(100 \mu \mathrm{M})$. All incubations with methoxamine were performed in the presence of yohimbine $(1 \mu \mathrm{M})$ to prevent a potential stimulation of $\alpha 2$-adrenergic receptors. Values at zero time correspond to the formation of ${ }^{3} \mathrm{H}$-cAMP over a $5 \mathrm{~min}$ period, estimated immediately after the $15 \mathrm{~min}$ Dl-induced desensitization and washing of the cells. Values are the means \pm SEM of data obtained in three experiments, each performed in triplicate. *, significantly different ( $p<0.05$, Student's $t$ test) when compared to control values.

also stimulates phospholipase $\mathrm{C}$ activity in cortical neurons, did not modify the resensitization of the D1 response (Table 1).

Lack of effect of methoxamine on the resensitization of the $\beta$-adrenergic-induced formation of $c A M P$ in cortical neurons

A 5 min incubation of cortical neurons with isoproterenol (1 $\mu \mathrm{M}$ ) resulted in a large formation of ${ }^{3} \mathrm{H}$-cAMP (see Fig. 5 legend). This $\beta$-adrenergic response was reduced ( $80 \%)$ following prior exposure (15 min) of the cells to isoproterenol $(1 \mu \mathrm{M})$ according to the procedure used for the estimation of the D1 DA-induced desensitization. The recovery of the full $\beta$-adrenergic response was more rapid than that of the D1 response since $75 \%$ of the initial response was restored $15 \mathrm{~min}$ after the removal of iso- 

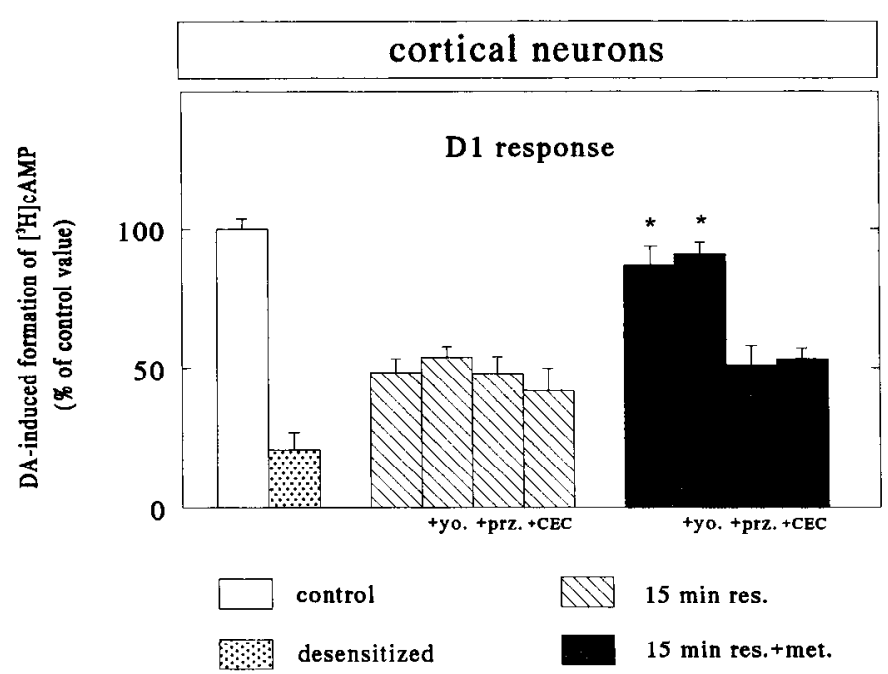

Figure 4. Effects of $\alpha 1$-adrenergic antagonists on the methoxamineinduced acceleration of the resensitization of the D1 response in cortical neurons. Experiments were performed with or without methoxamine $(100 \mu \mathrm{M}$, met.) as described in Figure 3. When used, yohimbine (yo., 1 $\mu_{\mathrm{M}}$ ) and prazosin ( $p r z ., 1 \mu \mathrm{M}$ ) were added without or with methoxamine during the $15 \mathrm{~min}$ resensitization period while chlorethylclonidine (CEC, $100 \mu \mathrm{M})$ was added $15 \mathrm{~min}$ before the desensitization period. Values are the mean \pm SEM of data obtained in triplicate from a typical experiment. Results are expressed as a percentage of the control D1 response. *, significantly different ( $p<0.05$, Student's $t$ test) from the control resensitized D1 response (15 min res.). Three other experiments performed with different neuronal cultures led to similar results.

proterenol (Fig. 5). In contrast to that observed for the D1 response, the addition of methoxamine $(100 \mu \mathrm{M})$ during the resensitization period did not affect the recovery of the $\beta$-adrenergic response (Fig. 6).

\section{Accelerated resensitization by glutamate, but not by methoxamine, of the DI DA-induced formation of CAMP in striatal neurons}

Confirming previous results (Chneiweiss et al., 1990), preincubation of striatal neurons with DA $(50 \mu \mathrm{M})$ in the presence of

\section{Table 1. Respective effects of methoxamine and glutamate on phospholipase $\mathrm{C}$ activity and on the resensitization of the D1 response in cortical neurons}

\begin{tabular}{|c|c|c|}
\hline & $\begin{array}{l}\text { PLC activation } \\
\text { (in \% of basal } \\
\text { activity) }\end{array}$ & $\begin{array}{l}\text { Effect on D1 } \\
\text { resensitization } \\
\text { (in \% of control } \\
\text { resensitized } \\
\text { response) }\end{array}$ \\
\hline \multicolumn{3}{|c|}{ Methoxamine } \\
\hline$(100 \mu \mathrm{M})$ & $191 \pm 7^{*}$ & $180 \pm 14^{* *}$ \\
\hline \multicolumn{3}{|l|}{ Glutamate } \\
\hline$(100 \mu \mathrm{M})$ & $242 \pm 12^{*}$ & $97 \pm 16$ \\
\hline \multicolumn{3}{|c|}{$\begin{array}{l}\text { The production of }{ }^{3} \mathrm{H} \text {-inositol phosphate induced by a } 5 \text { min incubation of cortical } \\
\text { neurons in the presence of either methoxamine or glutamate is expressed as a } \\
\text { percentage of the basal }{ }^{3} \mathrm{H} \text {-inositol phosphate formation. Values are the mean } \pm \\
\text { SEM of data obtained in three separate experiments, each being made in triplicate. } \\
\text { The effect of methoxamine or glutamate on the resensitization of the D1 response } \\
\text { was expressed as a percentage of the resensitized D1 response estimated under } \\
\text { control conditions (see Fig. 4). Values are the mean } \pm \text { SEM of three independent } \\
\text { experiments. }\end{array}$} \\
\hline \multicolumn{3}{|c|}{$\begin{array}{l}\text { * Significantly different }(p<0.05 \text {, Student's } t \text { test) from the basal value ( } 342 \pm \\
14 \mathrm{dpm} / \text { well). }\end{array}$} \\
\hline \multicolumn{3}{|c|}{$\begin{array}{l}* * \text { Significantly different ( } p<0.05 \text {, Student's } t \text { test) from the control resensitized } \\
\text { D1 response. }\end{array}$} \\
\hline
\end{tabular}

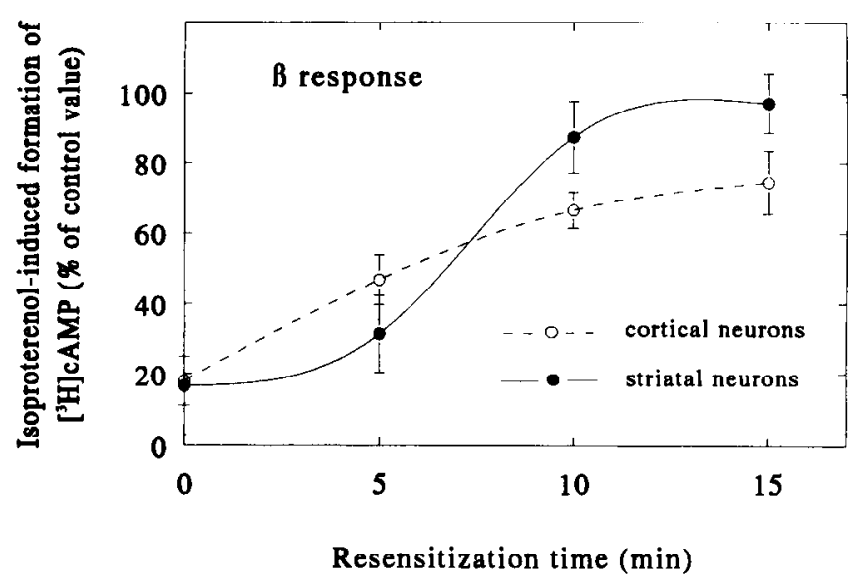

Figure 5. Resensitization of the $\beta$-adrenergic response in cortical and striatal neurons. The $\beta$-adrenergic-induced formation of ${ }^{3} \mathrm{H}$-cAMP was estimated by incubating neurons with isoproterenol $(1 \mu \mathrm{M})$ for $5 \mathrm{~min}$ $(\beta$-response). Desensitization was achieved by adding isoproterenol (1 $\mu \mathrm{M})$ for $10 \mathrm{~min}$. Following washing (scc Materials and Methods), cells were incubated for various times in the resensitization medium. Values at zero time correspond to the formation of ${ }^{3} \mathrm{H}$-cAMP over a $5 \mathrm{~min}$ period, estimated immediately after the $10 \mathrm{~min}$ isoproterenol-induced desensitization and washing of the cells. Results are expressed as a percentage of the control $\beta$-responses (control values). $\beta$-Responses represented $272 \pm 17$ and $436 \pm 23 \%$ of increase in basal ${ }^{3} \mathrm{H}$-cAMP formation in cortical and striatal neurons respectively, the basal ${ }^{3} \mathrm{H}$ cAMP levels being $247 \pm 36$ and $605 \pm 45$ d.p.m./well. Values are the means \pm SEM of data obtained in three experiments, each performed in triplicate.

sulpiride and propranolol induced a marked desensitization of the D1 response (Fig. 7). Indeed, the DA-induced formation of ${ }^{3} \mathrm{H}$-cAMP was markedly reduced $(-90 \%$ of the maximal D1 response) following a prolonged exposure of the cells to DA. Moreover, the resensitization of the striatal D1 response was more rapid than that observed in cortical neurons since the maximal D1 DA-induced formation of ${ }^{3} \mathrm{H}$-cAMP was almost completely restored $(95 \%)$ only $15 \mathrm{~min}$ after the removal of DA (Fig. 3).

Interestingly, in contrast to cortical neurons, the addition of methoxamine $(100 \mu \mathrm{M})$ during the resensitization period did not modify the rate of resensitization of the D1 response in striatal neurons (Fig. 3). However, this resensitization was accelerated by glutamate $(100 \mu \mathrm{M})$ (Fig. 7). Indeed, the full D1 response was observed as rapidly as $5 \mathrm{~min}$ after the beginning of the resensitization period in the presence of the excitatory amino acid. NMDA receptors appear to be involved in the glutamate-induced resensitization of the D1 response since the effect of glutamate was completely abolished in the presence of 2-amino5-phosphonovaleric acid (APV) $(50 \mu \mathrm{M})$, a competitive inhibitor of NMDA receptors (Fig. 7). In addition, the D,L- $\alpha$-amino-3hydroxy-5-methyl-4-isoxazole propionic acid (AMPA) antagonist 6,7-dinitroquinoxaline-2-3-dione(DNQX; $50 \mu \mathrm{M}$ ) was not effective (Fig. 7). Furthermore, 2-amino-3-phosphonopropionic acid (AP3; $1 \mathrm{~mm}$ ), an antagonist of metabotropic receptors coupled to phospholipase $\mathrm{C}$ was also without significant effect (Fig. 7).

As observed with $\mathrm{DA}$, the $\beta$-adrenergic agonist isoproterenol $(1 \mu \mathrm{M})$ stimulated the formation of ${ }^{3}$ II-cAMP in striatal neurons but this effect was less pronounced than that observed in cortical neurons (see Fig. 5 legend). Following a $15 \mathrm{~min}$ preexposure to isoproterenol, in order to desensitize the $\beta$-adrenergic receptors on these cells, a rapid resensitization of the $\beta$-adrenergic re- 

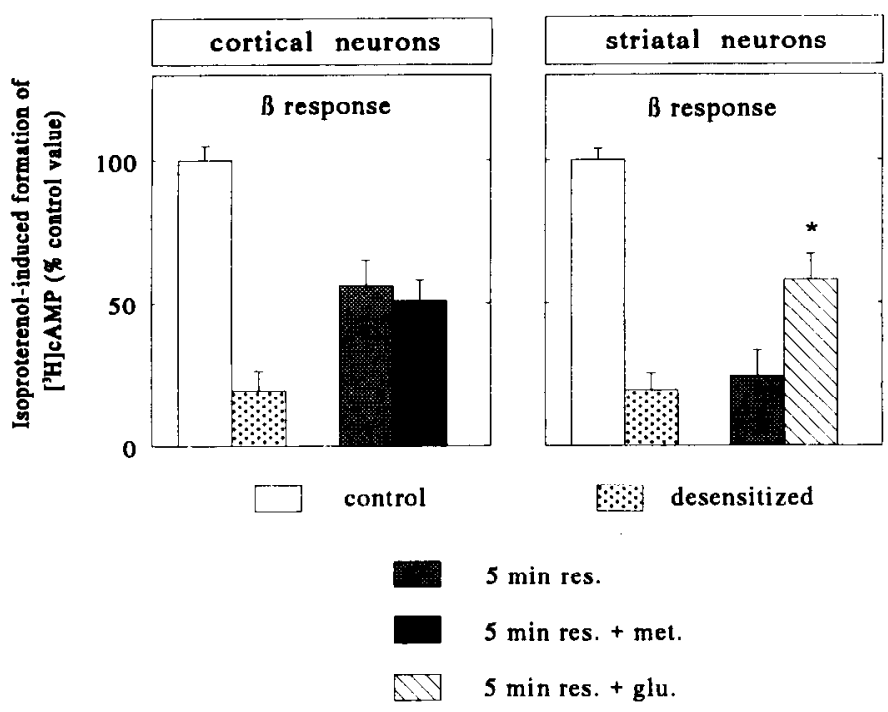

Figure 6. Respective effects of methoxamine and glutamate on the resensitization of the $\beta$-adrenergic response in cortical and striatal neurons. The $\beta$-adrenergic-induced formation of ${ }^{3} \mathrm{H}$-cAMP was estimated by incubating neurons with isoproterenol $(1 \mu \mathrm{M})$ for $5 \mathrm{~min}$ ( $\beta$-response). Desensitization and resensitization procedures were achieved as described for Figure 5. A 5 min resensitization period was chosen $(5 \mathrm{~min}$ res.). When used, methoxamine (met., $100 \mu \mathrm{M}$ ) was added during the resensitization period as described in Figure 4. Similarly, when used, glutamate (glu., $100 \mu \mathrm{M}$ ) was added during the beginning of the resensitization period. Values are the mean \pm SEM of data obtained in triplicate in a typical experiment. Results are expressed as a percentage of the control $\beta$-responses. Three other experiments made with different cultures led to similar results. ${ }^{*}$, significantly different $(p<0.05$, Student's $t$ test) from the corresponding control value ( 5 min res.).

sponse was observed since the initial maximal isoproterenolinduced formation of ${ }^{3} \mathrm{H}$-cAMP was seen after only $10 \mathrm{~min}$ of the resensitization period (Fig. 5). As demonstrated for the DI response, glutamate $(100 \mu \mathrm{M})$ also accelerated the resensitization of the $\beta$-adrenergic response (Fig. 6).

\section{Selective involvement of protein kinase $C$ in the $\alpha 1$-adrenergic accelerated resensitization of the $D 1$ response in cortical neurons}

As already indicated, $\alpha \mathrm{l}$ b-adrenergic receptors appear to be involved in the modulation of the resensitization of the cortical D1 DA-induced formation of ${ }^{3} \mathrm{H}$-cAMP. Since $\alpha 1 \mathrm{~b}$-adrenergic receptors are coupled to phospholipase C (Han et al., 1987), the stimulation of these receptors may result in a subsequent activation of protein kinase $\mathrm{C}(\mathrm{PKC})$. This led us to examine the effect of phorbol myristate acetate (PMA; 10 nM), a PKC-activating agent, on the resensitization rate of the $D 1$ response in cortical neurons.

The addition of PMA (10 nM) instead of methoxamine during the resensitization period accelerated the recovery of the D1 response in cortical neurons (Fig. 8). Interestingly, when added with DA, PMA altered neither the full DA-induced formation of ${ }^{3} \mathrm{H}$-cAMP (data not shown) nor the desensitization of the D1 response (Fig. 8). Furthermore, staurosporine $(0.5 \mu \mathrm{M})$, a nonselective inhibitor of PKC, markedly decreased the accelerating effect of methoxamine $(100 \mu \mathrm{M})$ on the resensitization of the D1 response (Table 2).

When cells were pretreated for $40 \mathrm{hr}$ with PMA (100 nM), a procedure known to downregulate the activity of $\mathrm{PKC}$, no modification of the DA-induced desensitization could be observed (Table 2). The involvement of PKC in the $\alpha 1$-adrenergic ac-

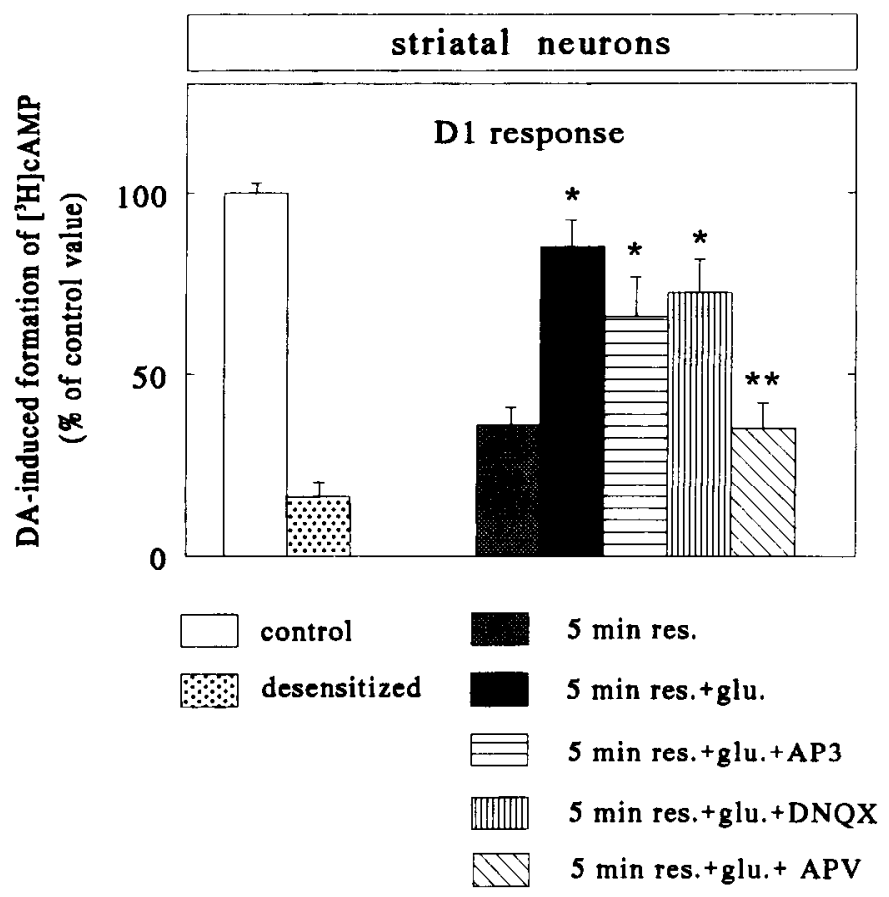

Figure 7. Accelerating effect of glutamate on the resensitization of the D1 response in striatal neurons: involvement of NMDA receptors. Desensitization with DA ( $50 \mu \mathrm{M}$, desensitized) and resensitization were performed as described for Figure 2, the D1 response ( 5 min formation of ${ }^{3} \mathrm{H}$-cAMP in the presence of $50 \mu \mathrm{M} \mathrm{DA}$ ) was estimated after a $5 \mathrm{~min}$ resensitization period ( $5 \mathrm{~min}$ res.), and glutamate $(g / u ., 100 \mu \mathrm{M})$ was added during the resensitization period. When used, AP3 (1 mM), DNQX $(50 \mu \mathbf{M})$, or APV $(50 \mu \mathbf{M})$ was added with glutamate. Data are the mean \pm SEM obtained in triplicate in a typical experiment; results are expressed as a percentage of the control D1 response. *, significantly different ( $p<0.05$, Student's $t$ test) when compared to the corresponding control value $\left(5 \mathrm{~min}\right.$ res.); ${ }^{* *}$, significantly different $(p<0.05$, Student's $t$ test) when compared to the corresponding glutamate value $(5 \mathrm{~min}$ res. + glu.).

celeration of the resensitization of the D1 response was further suggested by the suppression of the cffect of methoxaminc in PMA-pretreated cortical neurons (Table 2).

Surprisingly, in striatal neurons, the addition of PMA (10 nM) during the resensitization period did not modify the recovery of the D1 response, indicating that $\mathrm{PKC}$ is not involved in the accelerating effect of glutamate $(100 \mu \mathrm{M})$ on the resensitization of the D1 response (Fig. 8).

\section{Discussion}

The prolonged exposure of cells to hormones or neurotransmitters reduces their responsiveness to further stimulation. This desensitization process has been extensively described in numerous studies dealing with receptors coupled to adenylate cyclase, particularly for the $\beta$-adrenergic receptors (for review, see Huganir and Greengard, 1990). Briefly, the process of desensitization involves a rapid and reversible uncoupling of the receptors from the $\alpha$-subunits of G-proteins, followed by a slow reversible downregulation of the receptors. Two major mechanisms have been shown to be involved in the desensitization of $\beta$-adrenergic receptors: homologous desensitization, which involves a phosphorylation of the receptor by a $\beta$-adrenergic receptor-specific kinase ( $\beta$-ARK), and heterologous desensitization, in which the receptor is phosphorylated by cAMP-dependent protein kinase (Clark et al., 1990; Johnson et al., 1990; for review, see Huganir and Greengard, 1990). 


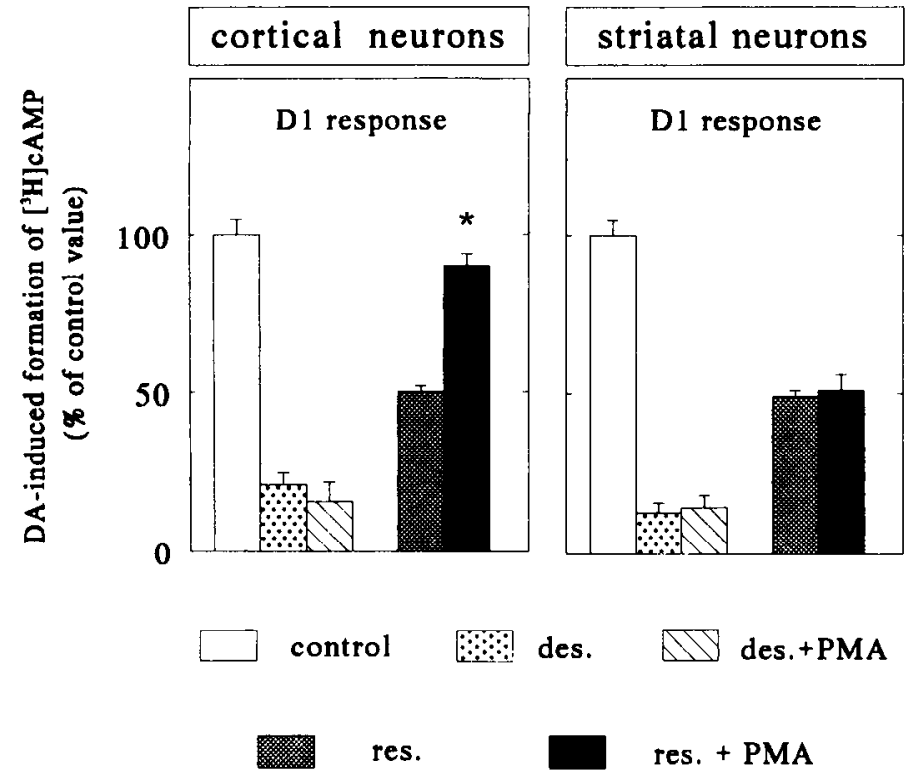

Figure 8. Effect of phorbol myristate acetate $(P M A)$ on the desensitization and on the resensitization of the D1 response in cortical and striatal neurons. Experiments with cortical and striatal neurons were performed as described for Figures 4 and 7 , respectively. PMA (10 nM) was added during the desensitization (des. $+P M A)$ or the resensitization period (res. $+P M A) .^{*}$, significantly different $(p<0.05$, Student's $t$ test) from the resensitized DI response (res.). Values are the mean \pm SEM of data obtained in triplicate in a typical experiment. Results are expressed as a percentage of the control Dl response. Three other experiments made with different cultures led to similar results.

\section{Desensitization of $D 1 D A$ receptors in cultured cortical and striatal neurons}

In contrast to $\beta$-adrenergic receptors, relatively little is known on the biochemical mechanisms involved in the regulation of D1 DA receptor sensitivity. Nevertheless, studies performed on cell cultures have demonstrated that desensitization of D1 DA receptors occurs following sustained exposure of neurons to DA (Balmforth et al., 1990; Barton and Sibley, 1990; Chneiweiss et al., 1990). A similar homologous desensitization has been observed in several in vivo studies in which striatal DA release was enhanced by amphetamine treatment (Barnett and $\mathrm{Ku}$ czenski, 1986; Robert-Lewis et al., 1986; Roseboom and Gnegy, 1989). In agreement with these observations, we demonstrated in the present study, that a 15 min preincubation with DA of either cortical or striatal neurons from the embryonic rat in primary culture resulted in a reversible decrease in the responsiveness of the D1 DA receptors to further DA stimulation, as estimated by the $5 \mathrm{~min}$ formation of ${ }^{3} \mathrm{H}$-cAMP in intact cells. This effect was indeed mediated by D1 DA receptors since the experiments were performed in the presence of sulpiride and propranolol to eliminate any possible interaction of $\mathrm{DA}$ with both D2 DA and $\beta$-adrenergic receptors. In addition, the DAinduced desensitization was suppressed in the presence of the D1 antagonist SCH 23390.

The rapid and complete recovery of the D1 response, which was faster in striatal than in cortical neurons, strongly suggests that this desensitization involved the uncoupling of D1 DA receptors from the $G$-protein linked to adenylate cyclase rather than a loss of receptors from neuronal membranes. In fact, longer periods of exposure to DA are required for the occurrence of a downregulation of D1 DA receptors (Chneiweiss et al., 1990; Bates et al., 1991). This rapid and reversible desensitization
Table 2. Effect of methoxamine on the resensitization of the D1 response in cortical neurons following long-term pretreatment with PMA

\begin{tabular}{lllll} 
& Des. & Res. & Res. +met. & $\begin{array}{l}\text { Res. }+ \text { met. } \\
+ \text { stauro. }\end{array}$ \\
\hline $\begin{array}{c}\text { Control } \\
\text { cortical neurons }\end{array}$ & $21.6 \pm 4$ & $47.7 \pm 5$ & $88.6 \pm 7^{*}$ & $42 \pm 9^{* *}$ \\
$\begin{array}{c}\text { PMA-pretreated } \\
\text { cortical neurons }\end{array}$ & $27.2 \pm 7$ & $37.2 \pm 5$ & $45.4 \pm 11^{* *}$ & -
\end{tabular}

Cortical neurons were pretreated for $48 \mathrm{hr}$ with PMA $100 \mathrm{nM}$; then, following extensive washing, the D1 desensitization (des.) and the resensitization (res.) of the D1 response in the presence (res.+ met.) or absence of methoxamine were induced and estimated as described for Figures 3 and 4, respectively. Staurosporine $(0.5 \mu \mathrm{M})$ was added with methoxamine during the resensitization period only in control cortical neurons. Results are expressed as a percentage of the control D1 response. Values represent the mean \pm SEM of data obtained in triplicate in a typical experiment. Three other experiments made with different neuronal cultures led to similar results.

* Significantly different ( $p<0.05$, Student's $t$ test) from the control resensitized D1 response (res.).

** Significantly different ( $p<0.05$, Student's $t$ test) from the corresponding value of the resensitized D1 response in the presence of methoxamine (res. + met.) in control cortical neurons.

process may result from the phosphorylation of the D1 DA receptors by a specific protein kinase as shown for $\beta$-adrenergic receptors (Balmforth et al., 1990).

Role of heterologous transmitters in the in vitro resensitization of the D1 response in cortical and striatal neurons

As already mentioned, little is known of the biochemical events underlying the resensitization of D1 DA receptor-mediated responses. Our study indicates that transmitters (or agonists) other than DA can play a prominent role in the regulation of the resensitization rate of the D1 DA-evoked formation of cAMP. Indeed, both methoxamine (through $\alpha 1$-adrenergic receptors) and glutamate (through NMDA receptors) can accelerate this resensitization process. However, these regulations are structure-specific since the $\alpha 1$-adrenergic acceleration of the resensitization of the D1 response was observed in cortical but not in striatal neurons while the reverse was found with glutamate. Finally, since there is no evidence for synaptic contacts in 6-dold neurons in primary culture (El Etr et al., 1989), a population of cortical neurons must possess both D1 DA and $\alpha 1$-adrenergic receptors while both DI DA and glutamatergic receptors should be colocalized on a population of striatal neurons. This is in agreement with electrophysiological studies indicating that some cortical cells in the prefrontal cortex are sensitive to both DA and noradrenaline (Bunney and Aghajanian, 1976) and that a population of striatonigral neurons possess both D1 DA and glutamatergic receptors (Cepeda et al., 1992).

\section{Acceleration of the resensitization of the $D 1$ response in cortical neurons by the $\alpha 1$-adrenergic agonist methoxamine}

Several observations demonstrated that the stimulation of $\alpha 1$ adrenergic receptors accelerates the resensitization of DI DA receptors coupled to adenylate cyclase in cortical neurons. Methoxamine accelerated the recovery of the full Dl response and this was even observed in the presence of yohimbine, which prevents the possible stimulation of $\alpha 2$-adrenergic receptors. Moreover, the effect of methoxamine was prevented by both prazosin, a nonselective $\alpha 1$-adrenergic antagonist, and CEC, which is known to inactivate $\alpha 1 \mathrm{~b}$-adrenoceptors irreversibly (Han et al., 1987). 
The specificity of the stimulatory effect of methoxamine on the resensitization of the D1 response was demonstrated in several ways. (1) The addition of methoxamine did not affect the full DA-induced formation of ${ }^{3} \mathrm{H}$-cAMP (before the desensitization or after the resensitization) or the DA-induced desensitization. (2) As shown by experiments made with isoproterenol, methoxamine did not affect the resensitization of the $\beta$-adrenergic-induced formation of ${ }^{3} \mathrm{H}$-cAMP in cortical neurons. (3) As previously indicated, methoxamine did not modify the rate of resensitization of the striatal D1 response.

Further studies will be necessary in order to elucidate the molecular mechanism(s) involved in the stimulatory effect of methoxamine on the DI DA receptor resensitization process. Nevertheless, our results already provide some preliminary indications. A possible modulation of phosphodiesterase activity, as suggested by Beavo and Reifsnyder (1990), can be excluded since all our experiments were performed in the presence of the non selective phosphodiesterase inhibitor 3-isobutyl-1-methylxanthine. As already indicated, $\alpha 1$ b-adrenergic receptors appear to be involved in the stimulatory effect of methoxamine. These receptors are coupled to phospholipase $C$, leading to the formation of diacylglycerol and inositol phosphates. Diacylglycerol and/or calcium mobilized from intracellular stores by inositol phosphates can stimulate PKC and therefore could potentially phosphorylate a protein involved in the accelerated resensitization of the $D 1$ response. The stimulatory effect of methoxamine persisted in both the absence of extracellular calcium or the presence of a calcium chelating agent (data not shown), suggesting that intracellular calcium could be eventually implicated in this process. Experiments performed with the phorbol ester PMA, which mimics the effect of diacylglycerol, support the involvement of PKC. Indeed, the direct activation of PKC by PMA reproduced the effect of methoxamine. Moreover, the prolonged (40 hr) preexposure of cortical neurons to PMA, a procedure that desensitizes PKC (Hepler et al., 1988), prevented the accelerating effect of methoxamine on the resensitization of the D1 response in cortical neurons. Providing further evidence for the involvement of distinct regulatory mechanisms in the desensitization and resensitization processes, the inactivation of PKC induced by long term pretreatment of cortical neurons with PMA did not affect the desensitization of D1 DA receptors. Experiments are in progress to identify the protein that is phosphorylated by PKC following exposure to methoxamine and is responsible for the accelerated recovery of the full DI DA response in cortical neurons.

\section{Acceleration by glutamate of the resensitization of the D1 response in striatal neurons}

Through cAMP formation and protein kinase $\mathrm{A}$ activation, the stimulation of DI DA receptors in the striatum leads via cAMP to the phosphorylation of DARPP 32, an inhibitor of phosphatase I (Hemmings et al., 1984). As elegantly shown, by acting on NMDA receptors, glutamate activates calcineurine, which dephosphorylates DARPP 32 and thus counteracts some of the effects of DA (Halpain et al., 1990). Interestingly, our study demonstratcs a ncw rcgulatory process of DA transmission by glutamate. Indeed, glutamate was found to accelerate the resensitization of the D1 DA-induced formation of ${ }^{3} \mathrm{H}-\mathrm{cAMP}$ in cultured striatal neurons.

NMDA receptors appear to be involved in the stimulatory effect of glutamate on the resensitization rate of striatal DI DA receptors. Indeed, the glutamate-induced facilitation of this re- sensitization process was totally prevented by $\Lambda \mathrm{PV}$, a competitive antagonist of NMDA receptors, while DNQX, an AMPA antagonist, was without effect. In addition to ionotropic receptors, striatal neurons in primary culture possess metabotropic glutamatergic receptors coupled to phospholipase C (Sladeczek et al., 1985). However, these receptors do not seem to be implicated in the stimulatory effect of glutamate. Indeed, the phorbol ester PMA did not accelerate the rate of recovery of the D1 response in striatal neurons, suggesting that $\mathrm{PKC}$ is not involved in this process. Confirming this finding, AP3, an antagonist of metabotropic receptors coupled to phospholipase C did not significantly modify the stimulatory effect of glutamate. Recent studies from our laboratory have demonstrated that a $G_{\text {olf }}$ protein is present in striatonigral neurons possessing D1 DA receptors (Hervé et al., 1993) and a specific adenylate cyclase sensitive to DA has recently been identified in the striatum (Glatt and Snyder, 1993). These observations could eventually explain why distinct intracellular biochemical events are involved in the regulation of the recovery of the full D1 DA response in cortical and striatal neurons.

Some specificity was also found in the stimulatory effect of glutamate on the resensitization of the striatal D1 DA receptors. Indeed, glutamate affected neither the full DA response nor the DA-induced desensitization. Moreover, glutamate did not affect the resensitization rate of the cortical D1 DA receptors although there is evidence, particularly in the prefrontal cortex, that there are cortical cells that are sensitive to both DA and glutamate (Pralong and Jones, 1993). However, glutamate also accelerated the resensitization of $\beta$-adrenergic receptors coupled to adenylate cyclase in striatal neurons, indicating that the glutamatergic and $\beta$-adrenergic receptors involved are colocalized on the same population of striatal neurons. These neurons could also possess D1 receptors since we have previously shown using additivity experiments that D1 DA and $\beta$-adrenergic receptors are in part colocalized in a population of striatal neurons (Chneiweiss et al., 1985).

\section{Relevance of the stimulatory effects of methoxamine and glutamate on the resensitization processes of cortical and striatal D1 receptors to in vivo findings}

Although the questions raised in the present study were suggested by in vivo findings, the interpretation of in vivo events in adult rats based on data obtained from cultured embryonic neurons can be criticized. For instance, the long term development of the denervation supersensitivity of the cortical or striatal D1 DA receptors may involve additional or different mechanisms than those implicated in the rapid resensitization processes described in the present study. In fact, it has been reported in several binding studies that following denervation, changes in the sensitivity of receptors coupled to adenylate cyclase are in most cases very likely to be associated with the appearance of new receptors on the postsynaptic neuronal membrane (Sporn et al., 1976). As already discussed, this is certainly not the case in our in vitro experimental paradigm. However, the amplitude of the full DA responses in cortical and striatal embryonic neurons, when compared to those observed in tissues of normal adult rats, suggests that D1 DA receptors in neuronal cultures are likely to be in an hypersensitive state. Although not strictly comparable, the hypersensitive D1 DA receptors in cultured neurons and in adult rats with denervation of DA neurons may thus have some common properties.

According to our in vivo data, the presence of the cortical 
noradrenergic innervation plays a prominent permissive role in the appearance of the denervation supersensitivity of the prefrontocortical D1 DA receptors (Tassin et al., 1986). Moreover, $\alpha 1$-adrenergic receptors sensitive to prazosin were shown to be involved in this heterologous receptor regulation (Trovero et al., 1992b). This is in agreement with our present results. Indeed, by acting on receptors colocalized on identical cortical neurons, methoxamine was found to accelerate the resensitization of the D1 response by stimulating $\alpha 1$-adrenergic receptors sensitive to prazosin. However, as indicated by autoradiographic studies performed on slices of the adult rat brain, D1 binding sites labeled with the D1 DA antagonist ligand, ${ }^{3} \mathrm{H}-\mathrm{SCH} 23390$, are mainly located in deep layers of the prefrontal cortex ( $\mathrm{V}$ and VI) while high-affinity ${ }^{3} \mathrm{H}$-prazosin binding sites are mainly concentrated in layer III (Trovero et al., 1992a). Nevertheless, as suggested by our in vitro results, this does not exclude the possibility that $\alpha 1$-adrenergic receptors sensitive to prazosin are located with the D1 DA receptors on a population of cortical cells. In fact, thesc $\alpha 1$-adrencrgic receptors could be partly distributed on apical dendrites of pyramidal neurons present in deep layers.

It is well established that the 6-OHDA-induced denervation of the nigrostriatal DA neurons leads to the development of the denervation supersensitivity of the striatal D1 DA receptors coupled to adenylate cyclase. Changes in signals conveyed by the corticostriatal glutamatergic neurons induced by bilateral alteration of catecholaminergic transmission in the prefrontal cortex prevent this denervation supersensitivity of striatal D1 DA receptors (Hervé et al., 1989). Moreover, D1 DA agonists have been shown to activate cFos expression in striatal neurons and these effects were found to be blocked by Dl antagonists (Robertson et al., 1989). The activation of adenylate cyclase is involved in this phenomenon since a positive regulation of $\mathrm{CFOS}$ by cAMP has been demonstrated and it was also shown that the cFos promotor contains onc or more cAMP response elements (Morgan and Curran, 1991). Interestingly, the D1 DA receptor-mediated cFos activation can be blocked by pretreatment with the NMDA glutamatergic antagonist MK801 (Snyder-Keller, 1991; Paul et al., 1992). Furthermore, in rats with unilateral 6-OHDA-induced lesion of the nigrostriatal DA neurons, both the marked Dl-induced activation of cFos in the ipsilateral striatum and the contralateral turning induced by the mixed D1 and D2 agonist apomorphine can be prevented by transection of corticostriatal afferents (Cenci and Björklund, 1993). Therefore, the full expression of the D1 receptor-mediated response depends on an intact glutamatergic corticostriatal input. Our in vitro results demonstrating that glutamate increases the rate of resensitization of D1 DA receptors by acting through NMDA receptors, can be compared with in vivo results. They provide the cellular basis for the modulation of DA transmission by glutamate through the effect of the excitatory amino acid on the sensitivity of D1 receptors coupled to adenylate cyclase in striatal target cells.

\section{References}

Balmforth AJ, Warburton P, Ball SG (1990) Homologous desensitization of the D1 dopamine receptor. J Neurochem 55:2111-2116.

Barnett JV, Kuczenski R (1986) Desensitization of rat striatal dopamine-stimulated adenylate cyclase after acute amphetamine administration. J Pharmacol Exp Ther 237:820-825.

Barton AC, Sibley DR (1990) Agonist-induced desensitization of D1dopamine receptors linked to adenylyl cyclase activity in cultured NS20Y neuroblastoma cells. Mol Pharmacol 38:531-541.
Bates MD, Caron MG, Raymond JK (1991) Desensitization of DAl dopamine receptors coupled to adenylate cyclase in opossum kidney cells. Am J Physiol 260:F937-F945.

Beavo JA, Reifsnyder DH (1990) Primary sequence of cyclic nucleotide phosphodiesterase isoenzymes and the design of selective inhihitors. Trends Pharmacol Sci 11:150-155.

Blanc G, Trovero F, Vezina F, Hervé D, Godeheu AM, Glowinski J, Tassin JP (1994) Blockade of prefronto-cortical $\alpha 1$-adrenergic receptors prevents locomotor hyperactivity induced by subcortical $d$-amphetamine injection. Eur J Neurosci 6:293-298.

Bunney BS, Aghajanian GK (1976) Dopamine and norepinephrine innervated cells in the rat prefrontal cortex. Pharmacological differentiation using microiontophoretic techniques. Life Sci 19:1783-1792.

Cenci MA, Björklund A (1993) Transection of corticostriatal afferents reduces amphetamine- and apomorphine-induced striatal fos expression and turning behaviour in unilaterally 6-hydroxydopamine-lesioned rats. Eur J Neurosci 5:1062-1070.

Cepeda C, Radisavljevic Z, Buchwald NA, Levine MS (1992) Dopamine receptor agonists alter responses evoked by excitatory amino acids in neostriatum and neocortex. Soc Neurosci Abstr 18:294-16.

Chneiweiss H, Glowinski J, Prémont J (1985) Modulation by monoamines of somatostatin-sensitive adenylate cyclase on neuronal and glial cells from the mouse brain in primary cultures. J Neurochem 44:1825-1831.

Chneiweiss H, Glowinski J, Prémont J (1990) Dopamine-induced homologous and heterologous desensitizations of adenylate cyclasecoupled receptors on striatal neurons. Eur J Pharmacol 189:287-292.

Clark RB, Friedman J, Dixon RAF, Strader CD (1990) Identification of a specific site required for rapid heterologous desensitization of the $\beta$-adrenergic receptor by cAMP-dependent protein kinase. Mol Pharmacol 36:343-348.

El Etr M, Cordier J, Glowinski J, Prémont J (1989) A neuro-glial cooperativity is required for the potentiation by 2-chloroadenosine of the muscarinic-sensitive phospholipase $C$ in the striatum. J Neurosci 9:1473-1480.

Glatt CE, Snyder SH (1993) Cloning and expression of an adenylyl cyclase localized to the corpus striatum. Nature 361:536-538.

Halpain S, Girault JA, Greengard P (1990) Activation of NMDA receptors induces dephosphorylation of DARPP-32 in rat striatal slices. Nature 343:369-372.

Han C, Abel PW, Minneman KP (1987) Heterogeneity of $\alpha 1$-adrenergic receptors revealed by chlorethylclonidine. Mol Pharmacol 32: 505-510.

Hemmings HC Jr, Greengard P, Tung HYL, Cohen P (1984) DARPP. 32 , a dopamine-regulated neuronal phosphoprotein, is a potent inhibitor of protein-phosphatase-1. Nature 310:503-505.

Hepler JR, Earp HS, Harden TK (1988) Long term phorbol ester treatment down-regulates protein kinase $C$ and sensitizes the phosphoinositide signalling pathway to hormone and growth factor stimulation. J Biol Chem 263:7610-7619.

Hervé D, Trovero F, Blanc G, Thierry AM, Glowinski J, JP Tassin (1989) Non-DA prefronto-cortical efferent fibers modulate D1 receptors denervation supersensitivity in specific regions of the rat striatum. J Neurosci 9:3699-3708.

Hervé D, Lévi-Strauss M, Marey-Semper I, Verney C, Tassin JP, Glowinski J, Girault JA (1993) $G_{\text {orr }}$ and $G_{s}$ in rat basal ganglia: possible involvement of $G_{\text {off }}$ in the coupling of dopamine $D 1$ receptor with adenylyl cyclase. J Neurosci 13:2237-2248.

Huganir RL, Greengard P (1990) Regulation of neurotransmitter receptor desensitization by protein phosphorylation. Neuron 5:555567.

Johnson JA, Clark RB, Friedman J, Dixon RAF, Strader CD (1990) Identification of a specific domain in the $\beta$-adrenergic receptor required for phorbol ester-induced inhibition of catecholamine-stimulated adenylyl cyclase. Mol Pharmacol 38:289-293.

Le Moal M, Cardo B, Stinus L (1969) Influence of ventral mesencephalic lesions on various spontaneous and conditioned behaviours in the rat. Physiol Behav 60:567-574.

Morgan JI, Curran T (1991) Stimulus-transcription coupling in the nervous system: involvement of the inducible proto-oncogenes fos and jun. Annu Rev Neurosci 14:421-451.

Paul ML, Graybiel AM, David JC, Robertson HA (1992) D1-like and D2-like dopamine receptors synergistically activate rotation and c-fos expression in the dopamine-depleted striatum in a rat model of Parkinson's disease. J Neurosci 10:3729-3742.

Pralong E, Jones RSG (1993) Interactions of dopamine with gluta- 
mate- and GABA-mediated synaptic transmission in the rat entorhinal cortex in vitro. Eur J Neurosci 5:760-767.

Roberts-Lewis JM, Roseboom PH, Iwaniec LM, Gnegy ME (1986) Differential down-regulation of D1-stimulated adenylate cyclase activity in rat forebrain after in vivo amphetamine treatments. J Neurosci 6:2245-2251.

Robertson HA, Peterson MR, Murphy K, Robertson GS (1989) D1dopamine receptor agonists selectively activate striatal c-fos independent of rotational behavior. Brain Res 503:346-349.

Roseboom PH, Gnegy ME (1989) Acute in vivo amphetamine produces a homologous desensitization of dopamine receptor-coupled adenylate cyclase activities and decreases agonist binding to the D1 site. Mol Pharmacol 34:148-156.

Salomon Y, Londos C, Rodbell M (1974) A highly sensitive adenylate cyclase assay. Anal Biochem 58:541-548.

Sladeczek F, Pin JP, Recasens M, Bockaert J, Weiss S (1985) Glutamate stimulates inositol phosphate formation in striatal neurons. $\mathrm{Na}$ ture 317:717-719.

Snyder-Keller AM (1991) Striatal c-fos induction by drugs and stress in neonatally dopamine-depleted rats given nigral transplants: importance of NMDA activation and relevance to sensitization phenomena. Exp Neurol 113:155-165.
Sporn JR, Harden TK, Wolfe BB, Molinoff PB (1976) $\beta$-Adrenergic receptor involvement in 6-hydroxydopamine-induced supersensitivity in rat cerebral cortex. Science 194:624-626.

Tassin JP, Stinus L, Simon H, Blanc G, Thierry AM, Le Moal M, Cardo B, Glowinski J (1978) Relationship between the locomotor hyperactivity induced by A10 lesions and the destruction of the frontocortical DA innervation in the rat. Brain Res 141:267-281.

Tassin JP, Simon H, Hervé D, Blanc G, LeMoal M, Glowinski J, Bockaert J (1982) Nondopaminergic fibers may regulate dopamine-sensitive adenylate cyclase in the prefrontal cortex and the nucleus accumbens. Nature 295:696-698.

Tassin JP, Studler JM, Hervé D, Blanc G, Glowinski J (1986) Contribution of noradrenergic neurons to the regulation of DA receptor denervation supersensitivity in rat prefrontal cortex. J Neurochem 46:243-248

Trovero F, Blanc G, Hervé D, Vézina P, Glowinski J, Tassin JP (1992a) Contribution of an $\alpha 1$-adrenergic receptor subtype to the expression of the "ventral tegmental area syndrome." Neuroscience 47:69-76.

Trovero F, Hervê D, Blanc G, Glowinski J, Tassin J (1992b) In vivo partial inactivation of dopamine D1 receptors induces hypersensitivity of cortical dopamine-sensitive adenylate cyclase: permissive role of $\alpha 1$-adrenergic receptors. J Neurochem 59:331-337. 